\title{
PENGETAHUAN DAN PEMILIHAN OBAT TRADISIONAL OLEH IBU-IBU DI SURABAYA
}

\author{
Arina Rahma Oktaviani, Azan Takwiman, Desyta Ajeng Trisna Santoso, Elma Oktavia Hanaratri, Errina \\ Damayanti, Lailatul Maghfiroh, Mega Meiana Putri, Nofika Agung Maharani, Risda Maulida, Viola \\ Arsideva Oktadela, Ana Yuda*
}

Fakultas Farmasi, Universitas Airlangga

Gedung Nanizar Zaman Joenoes Kampus C, Jl. Ir. Soekarno, Surabaya 60115, Indonesia

E-mail: ana-y@ff.unair.ac.id

\begin{abstract}
ABSTRAK
Penelitian ini dilakukan untuk mengidentifikasi pengetahuan dan pemilihan obat tradisional oleh ibu-ibu di Surabaya, menggunakan metode cross sectional dan instrumen berupa kuesioner. Responden dalam penelitian ini adalah 150 ibu-ibu yang sudah atau pernah berkeluarga, memiliki anak, dan sedang atau pernah mengkonsumsi obat tradisional dalam waktu 2 bulan terakhir. Teknik sampling dilakukan secara non random. Hasil yang didapat, $1.33 \%$ responden mempunyai tingkat pengetahuan rendah, $62,67 \%$ responden mempunyai tingkat pengetahuan sedang, dan 36\% responden mempunyai tingkat pengetahuan tinggi. Masalah kesehatan yang pernah ditangani dengan obat tradisional paling banyak secara berturutturut adalah pegal linu/nyeri, batuk pilek, dan demam. Sebanyak 86 responden memilih menggunakan obat tradisional sebagai upaya pencegahan, 48 responden menjadikan sebagai pilihan utama setiap mengalami gangguan kesehatan, dan 31 reponden menggunakan ketika penyakit tidak membaik dengan obat modern. Sebagian besar responden memilih kerabat atau teman sebagai sumber informasi dalam pemilhan obat tradisional dan hanya 17 yang bertanya kepada tenaga kesehatan. Pada saat menerima terapi obat modern, 36 responden menghentikan penggunaan obat tradisional, sementara 18 responden menggunakan keduanya tanpa berkonsultasi dengan tenaga kesehatan. Tempat mendapatkan obat tradisonal yang paling banyak adalah apotek sebanyak 45 responden, toko kelontong sebanyak 35 responden, dan 33 responden membeli dari toko obat cina (istilah lokal untuk toko obat yang dikelola atau dimiliki oleh etnis Tionghoa).
\end{abstract}

Kata Kunci: Pengetahuan, Pemilihan, Obat Tradisional

\begin{abstract}
This research was conducted to identify the knowledge and selection of traditional medicine by mothers in Surabaya, using cross sectional methods and a questionnaire instrument. Respondents in this study were 150 mothers who have or have had families, have children, and are currently or have consumed traditional medicine in the last 2 months. The sampling technique is non random. The results obtained, $1.33 \%$ of respondents have a low level of knowledge, $62.67 \%$ of respondents have a moderate level of knowledge, and $36 \%$ of respondents have a high level of knowledge. Health problems that have been treated with traditional medicine at most in succession are aches / pains, cough, cold and fever. A total of 86 respondents chose to use traditional medicine as a preventive measure, 48 respondents made it their main choice whenever they experienced health problems, and 31 respondents used it when the disease did not improve with modern medicine. Most of the respondents chose relatives or friends as a source of information on the selection of traditional medicines and only 17 asked health workers. When receiving modern drug therapy, 36 respondents stopped using traditional medicines, while 18 respondents used both without consulting health personnel. Where to get the most traditional medicines is a pharmacy with 45 respondents, a grocery store with 35 respondents, and 33 respondents who buy from a Chinese medicine shop (a local term for a drug store that is managed or owned by ethnic Chinese).
\end{abstract}

Keywords: Knowledge, Selection, Traditional Medicine 


\section{PENDAHULUAN}

Obat tradisional merupakan bahan atau ramuan yang berupa tumbuhan, hewan, mineral, sediaan sarian (galenik) atau campuran dari bahan tersebut yang secara turun temurun telah digunakan untuk pengobatan, dan dapat diterapkan sesuai dengan norma yang berlaku di masyarakat (BPOM, 2014). Perkembangan selanjutnya obat tradisional kebanyakan berupa campuran yang berasal dari tumbuh-tumbuhan sehingga dikenal dengan obat herbal. (Oka, 2016) .Di Indonesia, obat herbal sebagai bagian dari obat bahan alam Indonesia dapat dikelompokkan menjadi 3 kelompok, yakni : jamu, obat herbal terstandar dan fitofarmaka (BPOM, 2005). Secara umum 92\% masyarakat menyatakan bahwa mereka mengetahui tentang obat tradisional, namun ketika ditanya lebih spesifik mengenai pengembangan obat tradisional sebagai obat herbal, mayoritas masyarakat $88,2 \%$ hanya mengenal jamu sedangkan yang mengetahui jenis obat herbal terstandar 29,4\% dan yang mengenal Fitofarmaka 3\% (Pratiwi et al. 2018).

Penggunaan Obat herbal telah diterima secara luas di negara berkembang dan di negara maju. Menurut WHO, hingga $65 \%$ dari penduduk negara maju dan $80 \%$ penduduk negara berkembang telah menggunakan obat herbal (Hidayat, 2006). Mayoritas pengguna didominasi oleh pasien perempuan (72\%) dengan profil penyakit yang diobati dengan obat herbal yaitu penyakit Diabetes Mellitus ada pada persentase tertinggi $(28,57 \%)$, hipertensi, hiperkolesterol dan nyeri sendi masing-masing $17,85 \%$, batu ginjal dan diare masing-masing $7,14 \%$ dan asma 3,57\% (Muthaharah et al. 2017).

Salah satu persyaratan obat tradisional yang harus dipenuhi menurut PERMENKES RI No.007 tahun 2012 pada pasal 7 adalah obat tradisional tidak boleh mengandung satu atau lebih bahan kimia obat atau merupakan hasil isolasi maupun sintetik berkhasiat obat. Meski sudah ada undang-undang tentang bahan-bahan yang dilarang dan persyaratan peredaran obat di Indonesia, persoalan yang masih terjadi lemahnya pengawasan pemerintah seperti ditemukannya penambahan bahan kimia obat (BKO) kedalam produk jamu. Berdasarkan data terakhir BPOM 2014 menemukan 51 obat tradisional yang mengandung BKO, dimana 42 diantaranya merupakan produk ilegal. Pada tahun 2012 dilakukan penarikan obat Teratai Putih Kapsul/ TR043230731 karena terbukti mengandung Paracetamol dan Natrium Diklofenak dan tidak memiliki izin edar
(Health, 2012). Distribusi obat tradisional bisa diakses darimanapun salah satunya yaitu melalui penjualan online. Penjualan obat tersebut akan memiliki pasar yang lebih luas, harga lebih murah, dan lebih cepat, namun di Indonesia saat ini belum memiliki regulasi terkait dengan penjualan obat melalui media online, sehingga obat-obatan tersebut sangat rentan dapat disalahgunakan peruntukannya oleh masyarakat atau digunakan dengan cara yang salah, yang tanpa disadari akan membahayakan kesehatan dan bahkan menimbulkan korban (Ariyulinda, 2018).

Persyaratan lainnya adalah bahwa obat tradisional yang beredar harus memenuhi persyaratan khasiat, keamanan, dan penandaan. Dalam hal tersebut ternyata banyak juga beredar obat tradisional yang tidak teregistrasi terutama yang dijual secara online. Dengan adanya berbagai permasalahan obat tradisional, dilakukan penelitian untuk mengetahui pengetahuan dan pemilihan obat tradisional oleh ibu-ibu di Surabaya. Penelitian ini diharapkan dapat menjadi data awal untuk mengambil langkah dalam peningkatkan pengetahuan masyarakat mengenai obat tradisional dan meningkatkan kepedulian serta mengetahui cara pemilihan obat tradisional yang tepat agar aspek keamanan, khasiat, dan mutu obat tetap terjamin sehingga dapat dijadikan salah satu alternatif dalam memnyelesaikan permasalahan kesehatan di masyarakat.

\section{METODE PENELITIAN}

Metode penelitian yang dipilih adalah observasional dengan pendekatan crosssectional. Teknik sampling secara non- random yaitu accidental sampling dan instrumen yang digunakan berupa lembar penjelasan kepada responden, lembar pernyataan persetujuan menjadi responden, dan kuesioner. Pengambilan data dilakukan saat kegiatan Car Free Day di Taman Bungkul Surabaya pada tanggal 8 September 2019. Besar sampel pada penelitian ini sebanyak 150 responden, dengan kriteria yaitu Ibu-ibu yang sudah atau pernah berkeluarga, memiliki anak, dan pernah atau sedang mengkonsumsi obat tradisional selama dua bulan terakhir. Pemilihan tersebut karena mempertimbangkan peran ibu yang umumnya paling berkontribusi untuk mengambil keputusan pengobatan untuk keluarganya baik itu obat konvensional maupun obat tradisional (Gerald, 2018). 
Pengambilan data dilakukan dengan cara mendatangi ibu-ibu di area Car Free Day, kemudian peneliti menjelaskan syarat atau kriteria responden penelitian. Apabila calon responden tersebut memenuhi kriteria maka diminta menandatangani persetujuan untuk menjadi responden. Setelah itu, responden diminta untuk mengisi kuesioner yang membutuhkan waktu 10-15 menit. Setelah responden selesai mengisi kuesioner, peneliti memberikan kenang-kenangan kepada responden sebagai tanda terima kasih.

Pengujian validitas yang dilakukan pada instrumen penelitian adalah validitas rupa dengan cara penilaian subyektif dari pakar dan uji coba kepada subyek yang mempunyai ciri hampir sama dengan responden. Uji coba dilakukan pada ibu-ibu di daerah tempat tinggal peneliti dengan cara mendampingi proses pengisian kuesioner untuk melihat apakah ada kalimat yang tidak jelas atau bias. Hasil pengujian digunakan untuk memperbaiki kuesioner hingga akhirnya kuesioner siap digunakan sebagai instrumen penelitian.

Variabel yang diteliti adalah pengetahuan dan pemilihan obat tradisional oleh ibu-ibu di Surabaya. Variabel pengetahuan terdiri dari 15 pertanyaan dengan skor 0 untuk jawaban salah dan skor 1 untuk jawaban benar. Responden yang memiliki total skor 0-5 digolongkan dalam tingkat pengetahuan rendah, 6-10 memiliki pengetahuan sedang, dan total skor 11-15 memiliki pengetahuan tinggi. Pada Variabel pemilihan, pertanyaan berupa pilihan ganda dimana responden boleh memilih lebih dari satu jawaban yang sesuai dengan kondisi responden dan tidak ada skoring. Penyajian hasil dalam bentuk tabel frekuensi dan persentase.

\section{HASIL DAN PEMBAHASAN}

Dari hasil pengolahan data, didapatkan data demografi yang menunjukkan distribusi usia responden rata-rata berusia 35-44 tahun seperti tertera pada Gambar 1. Mayoritas pendidikan terakhir responden adalah SMA/SMK dan dapat diketahui bahwa mayoritas responden adalah ibu rumah tangga sesuai yang tertera pada Tabel 1.

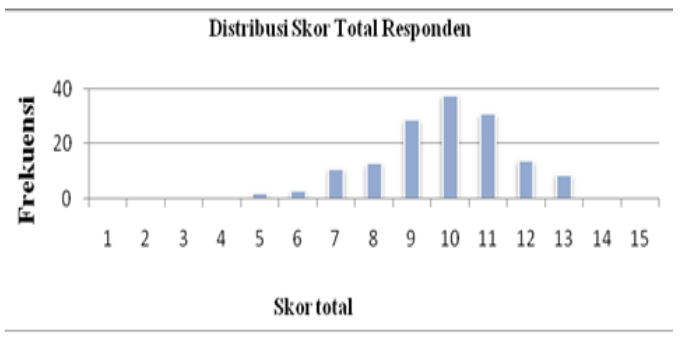

Gambar 1. Distribusi Skor Total Responden

Tabel 1. Demografi Usia, Pendidikan Terakhir, dan Pekerjaan Responden

\begin{tabular}{|c|c|c|}
\hline Demografi & Kategori & $\begin{array}{c}\text { Frekuensi } \\
\mathrm{n}(\%)\end{array}$ \\
\hline \multirow{6}{*}{ Usia } & $<25$ tahun & 5 \\
\hline & 25-34 tahun & 26 \\
\hline & 35-44 tahun & 40 \\
\hline & 45-54 tahun & 23 \\
\hline & 55-64 tahun & 5 \\
\hline & $\geq 65$ tahun & 1 \\
\hline \multirow{6}{*}{$\begin{array}{c}\text { Pendidikan } \\
\text { terakhir }\end{array}$} & SD & 4 \\
\hline & SMP & 6 \\
\hline & SMA/SMK & 55 \\
\hline & Diploma & 9 \\
\hline & Sarjana & 23 \\
\hline & Tidak diketahui & 3 \\
\hline \multirow{6}{*}{ Pekerjaan } & IRT & 55 \\
\hline & Wiraswasta & 27 \\
\hline & Lainnya & 8 \\
\hline & PNS & 3 \\
\hline & Pedagang & 3 \\
\hline & Guru & 4 \\
\hline
\end{tabular}

Pada Tabel 2 menunjukan bahwa terdapat 94 responden $(62,67 \%)$ dengan kategori pengetahuan sedang. Banyaknya responden yang memiliki pengetahuan sedang terkait obat tradisional perlu adanya peningkatan pengetahuan, karena kebanyakan obat tradisional dipilih untuk swamedikasi sehingga ketepatan dalam memilih dan menggunakan obat tradisional menjadi hal yang perlu diperhatikan.

Tabel 2. Distribusi Tingkat Pengetahuan Responden

\begin{tabular}{lll}
\hline \multicolumn{1}{c}{ Kategori } & \multicolumn{1}{c}{ Skor } & \multicolumn{1}{c}{$\mathrm{n}(\%)$} \\
\hline Rendah & $0-5$ & $2(1,33)$ \\
\hline Sedang & $6-10$ & $94(62,67)$ \\
\hline Tinggi & $11-15$ & $54(36)$ \\
\hline & Jumlah & $150(100)$ \\
\hline \hline
\end{tabular}


Pada Tabel 3 menunjukkan terdapat 70 responden $(46,67 \%)$ mengetahui bahwa tanaman di Indonesia ternyata tidak dapat digunakan sebagai obat tradisional sedangkan sisanya sebanyak 80 responden $(53,33 \%)$ tidak mengetahui hal itu. Padahal sebenarnya di Indonesia terdapat banyak tanaman berbahaya yang mengandung racun, yang menimbulkan segala macam efek atau reaksi merugikan seperti alergi, dermatitis, dan lain lain. Contohnya adalah tanaman anthurium (gelombang cinta), dieffenbachia (beras wetah), dan lain lain (Bruce, 2013). Oleh karena itu, perlu adanya edukasi kepada masyarakat untuk berhati-hati dalam memilih tanaman yang akan dijadikan sebagai obat.

Tabel 3. Profil Pengetahuan Responden Mengenai Obat Tradisional

\begin{tabular}{|c|c|}
\hline Persyaratan & $\begin{array}{c}\text { Jawaban } \\
\text { benar n }(\%)\end{array}$ \\
\hline $\begin{array}{l}\text { Semua tanaman di Indonesia dapat } \\
\text { digunakan sebagai obat tradisional }\end{array}$ & $80(53,33)$ \\
\hline $\begin{array}{l}\text { Obat tradisional dapat dikonsumsi } \\
\text { berbagai kalangan usia }\end{array}$ & $61(40,67)$ \\
\hline $\begin{array}{l}\text { Tanaman yang sudah diproses } \\
\text { dalam kemasan dengan bentuk } \\
\text { tablet bukan merupakan obat } \\
\text { tradisional }\end{array}$ & $80(53,33)$ \\
\hline $\begin{array}{l}\text { Obat tradisional tidak boleh } \\
\text { mengandung bahan kimia obat }\end{array}$ & $128(85,33)$ \\
\hline $\begin{array}{l}\text { Obat tradisional tidak memiliki } \\
\text { efek samping }\end{array}$ & $44(29,33)$ \\
\hline $\begin{array}{l}\text { Informasi produk obat tradisional } \\
\text { dari internet selalu dapat dipercaya }\end{array}$ & $107(71,33)$ \\
\hline $\begin{array}{l}\text { Obat tradisional wajib memiliki } \\
\text { nomor registrasi }\end{array}$ & $37(24,67)$ \\
\hline $\begin{array}{l}\text { Pada tiap kemasan obat tradisional } \\
\text { terdapat logo untuk membedakan } \\
\text { jenisnya }\end{array}$ & $141(94)$ \\
\hline $\begin{array}{l}\text { Terdapat beberapa tingkatan obat } \\
\text { tradisional berdasarkan tingkat } \\
\text { pengujian khasiat dan keamanan }\end{array}$ & $140(93,33)$ \\
\hline $\begin{array}{l}\text { Obat tradisional selalu aman } \\
\text { digunakan dengan obat-obat } \\
\text { modern }\end{array}$ & $84(56)$ \\
\hline $\begin{array}{l}\text { Obat tradisional yang berasal dari } \\
\text { luar negeri (China, Arab, dll) boleh } \\
\text { beredar tanpa registrasi dari BPOM }\end{array}$ & $122(81,33)$ \\
\hline $\begin{array}{l}\text { Banyak obat tradisional palsu yang } \\
\text { beredar di masyarakat }\end{array}$ & $135(90)$ \\
\hline $\begin{array}{l}\text { Jamu gendong dan usaha jamu } \\
\text { merupakan } \\
\text { tradisional }\end{array}$ & $144(96)$ \\
\hline $\begin{array}{l}\text { Usaha jamu racikan dan jamu } \\
\text { gendong diperbolehkan tidak } \\
\text { memiliki izin edar }\end{array}$ & $89(59,33)$ \\
\hline $\begin{array}{l}\text { Obat tradisional dapat dikonsumsi } \\
\text { tanpa aturan pakai (sewaktu-waktu) }\end{array}$ & $84(56)$ \\
\hline
\end{tabular}

Terdapat $80(53,33 \%)$ responden mengetahui obat tradisional yang dikemas dalam bentuk tablet sedangkan $70 \quad(46,67 \%)$ responden lainnya tidak mengetahui hal itu. Padahal obat bentuk tablet tidak sudah banyak beredar masyarakat, tetapi masyarakat kurang memperhatikan golongan obat yang diminumnya. Sehingga masih banyak masyarakat mengira bahwa obat dengan bentuk tablet bukan termasuk obat tradisional. Peraturan Kepala Badan Pengawas Obat Dan Makanan Republik Indonesia Nomor 35 Tahun 2013 Tentang Tata Cara Sertifikasi Cara Pembuatan Obat Tradisional Yang Baik menjelaskan macam bentuk tablet pada obat tradisional meliputi tablet salut, tabet hisap, kaplet, tablet kunyah dan tablet effervescent. Sedangkan contoh obat tradisional bentuk tablet yang sering beredar masyarakat dari golongan jamu contohnya Tolak Angin, Antangin, dan Kuku Bima Gingseng, golongan Obat Herbal Standar seperti Diapet, Lelap, dan Glucogarp, serta dari golongan fitofarmaka seperti Stimuno, Tensigard, dan Nodiar.

Terdapat $22(15,67 \%)$ responden menjawab bahwa obat tradisional dapat mengandung bahan kimia obat, yang mana sangat berisiko bagi kesehatan apabila masyarakat tidak mengetahui bahaya dari kandungan bahan kimia obat yang terdapat dalam obat tradisional tersebut. Sebagai contoh terdapat jamu cap "Akar Dewa" yang ditemukan di kota Samarinda dan jamu pelangsing yang mengandung fenolftalein (Siahaan et al. 2017). Selain itu, terdapat obat-obatan yang mengandung steroid yang bisa mempercepat osteoporosis, misalnya prednison, prednisolon, kortison, termasuk jamu atau obat tradisional yang biasanya juga mengandung steroid, yang diberikan pada penyakit rematik, asma, radang usus atau beberapa penyakit kanker. Makin tinggi dosis dan makin lama pemakaian, resiko osteoporosis menjadi makin besar (Wirastuti et al. 2016).

Pada umumnya penggunaan obaat tradisional relatif lebih aman dari obat modern, karena obat tadisional memiliki efek samping lebih sedikit dibanding obat modern. Dari Tabel 4 dapat diketahui bahwa frekuensi jawaban benar pada nomor soal 5 hanya 44 responden $(29,33 \%)$ dari 150 responden. Hal tersebut menunjukkan bahwa masyarakat belum sepenuhnya tau bahwa obat tradisional juga ada yang memiliki efek samping. Obat tradisional yang memberi efek samping dapat dikarenakan oleh adanya toksisitas intrinsik/ekstrinsik dari campuran beberapa macam tanaman, interaksi antar komponen, penggunaan kronik, atau 
interaksi dengan obat modern/konvesional yang dikonsumsi secara bersamaan (Gitawati et al. 2007).

Berdasarkan hasil survey mengenai informasi produk obat tradisional dari internet selalu dapat dipercaya diperoleh hasil sebanyak $43(28,67 \%)$ dari 150 responden menjawab salah. Hal tersebut menunjukkan bahwa terdapat beberapa responden yang menganggap seluruh informasi dari internet selalu benar, padahal tidak demikian. Seperti kasus yang terjadi di Jakarta, yaitu penyitaan 330 produk online obat tradisional yang dilakukan oleh BPOM RI, dimana keseluruhan obat tradisional tersebut dinyatakan ilegal lantaran tidak memiliki izin edar (Apriliani et al, 2017). Berdasarkan hasil pengawasan tahun 2015 yang dilakukan oleh Balai Besar POM Surabaya terhadap penjualan obat tradisional dan kosmetika yang dijual secara online yaitu 50 persen obat tradisional dan kosmetik yang dijual secara online adalah palsu (Ariyulinda, 2018). Produk obat tradisional dapat dipastikan keamanannya dengan cara menerapkan Cek KLIK (Kemasan, Label, Izin Edar, dan Kadaluwarsa) melalui aplikasi Cek BPOM (Pusat Data dan Informasi Obat dan Makanan 2018). Melalui program tersebut masyarakat diharapakan lebih berhatihati dalam memilih produk obat tradisional serta mencegah terjadinya penggunaan obat yang tidak sesuai regulasi yang dapat menimbulkan gangguan kesehatan.

Terdapat $37 \quad(24,67 \%) \quad$ responden menganggap bahwa semua obat tradisional wajib memiliki nomor registrasi. Anggapan tersebut tidak benar, karena menurut Permenkes RI (2012) Nomor 7 pasal 4 menyatakan bahwa obat tradisional yang diedarkan di wilayah Indonesia wajib memiliki izin edar, kecuali obat tradisional yang dibuat oleh usaha jamu racikan dan usaha jamu gendong. BPOM melakukan survei kepada masyarakat dan menunjukkan bahwa sekitar 50\% masyarakat membeli obat dan makanan dengan hati-hati (Siahaan et al. 2017). Oleh karena itu, perlu adanya edukasi kepada masyarakat yang tepat mengenai peredaran obat tradisional di Indonesia dan obat tradisional yang tidak perlu nomor registrasi untuk izin edarnya agar tidak menimbulkan persepsi yang salah atau kurang tepat.

Banyak laporan menunjukkan bahwa obatobatan tradisional sering dipakai bersamaan dengan terapi konvensional, penggunaan obat tradisional bersamaan dengan obat-obatan modern tidak selalu aman digunakan secara bersamaan, adanya interaksi antar obat sangat perlu untuk diwaspadai (Widia et al. 2018). Dokter Arijanto mencontohkan obat herbal dengan bahan baku ginseng untuk penambah stamina sebaiknya tidak diminum bersamaan dengan obat-obat penyakit jantung. Ini karena keduanya dapat memicu aritmia atau ketidakteraturan ritme detak jantung (Anna, 2014). Namun dari hasil penelitian, ada sekitar $80 \quad(56 \%)$ responden yang beranggapan obat tradisional selalu aman digunakan bersamaan dengan obat-obatan modern. Hal ini perlu adanya peningkatan pengetahuan terkait bahaya interaksi obat kepada masyarakat.

Hasil survey menunjukkan masih banyak responden yang kurang mengetahui bahwa obat tradisional yang berasal dari luar negeri tidak boleh beredar tanpa registrasi dari BPOM, sehingga obat tradisional yang mengandung BKO dan obat-obatan palsu atau legal masih banyak beredar di masyarakat.Pada dasarnya salah satu untuk menjamin keamanan masyarakat yaitu dengan teregistrasinya obat tradisional oleh BPOM .Contohnya pada kasus ditemukan obat tradisional produksi luar negeri atau impor yang tidak memiliki izin edar. Pada tahun 2012 dilakukan penarikan obat Teratai Putih Kapsul/ TR043230731 karena terbukti mengandung paracetamol dan natrium Diklofenak dan tidak terdaftar tetapi mencantumkan No Izin Edar fiktif (Health, 2012).

Pada Tabel 4 juga diketahui mengenai aturan penggunaan obat tradisional bahwa jawaban benar pada nomor soal 15 mendapat frekuensi $84(56 \%)$ responden dari 150 responden. Sehingga masih ada sebagian masyarakat yang tidak mengetahui bahwa obat tradisional (OT) juga perlu dikonsumsi dengan aturan pakai. Tanaman obat juga mempunyai dosis dan aturan pakai yang harus dipatuhi seperti halnya resep dokter. Sebagai contohnya buah mahkota dewa dimana perbandingannya dengan air adalah 1:3 artinya untuk menkonsumsi 1 buah memerlukan 3 gelas air. Sementara daun mindi akan menimbulkan khasiat jika direbus sebanyak 7 lembar dengan takaran air tertentu (Suarni, 2005). Selain dosis dan takaran untuk mengonsumsi tanaman obat harus tepat, waktu penggunaan juga harus tepat untuk meminimalisisasi efek samping yang timbul. Sebagai salah satu contoh adalah kunyit. Kunyit yang dipercaya dapat mengurangi nyeri pada saat haid justru dapat menyebabkan terjadi keguguran apabila dikonsumsi pada awal masa kehamilan. (Sumayyah et al. 2017) 
Tabel 4. Pemilihan obat tradisional

\begin{tabular}{|c|c|c|}
\hline Parameter & Pemilihan Jawaban & Frekuensi n (\%) \\
\hline \multirow{6}{*}{$\begin{array}{l}\text { Masalah kesehatan } \\
\text { yang pernah } \\
\text { ditangani dengan obat } \\
\text { tradisional }\end{array}$} & Pegel linu/nyeri & $77(51,3 \%)$ \\
\hline & Batuk/pilek & $62(41,3 \%)$ \\
\hline & Panas/demam & $41(27,3 \%)$ \\
\hline & Darah tinggi & $16(10,6 \%)$ \\
\hline & Diabetes & $15(10,0 \%)$ \\
\hline & Lain-lain & $4(2,6 \%)$ \\
\hline \multirow{5}{*}{$\begin{array}{l}\text { Waktu penggunaan } \\
\text { obat tradisional }\end{array}$} & Sebelum sakit sebagai upaya pencegahan & $86(57,3 \%)$ \\
\hline & Sebagai pilihan utama setiap mengalami gangguan kesehatan & $48(32,0 \%)$ \\
\hline & Jika penyakit tidak membaik dengan obat-obat modern & $31(20,6 \%)$ \\
\hline & Mengonsumsi bersama dengan obat modern & $7(4,6 \%)$ \\
\hline & Lain-lain & $4(2,6 \%)$ \\
\hline \multirow{4}{*}{$\begin{array}{l}\text { Hal yang dilakukan } \\
\text { ketika menggunakan } \\
\text { obat tradisional } \\
\text { bersamaan dengan } \\
\text { obat dari dokter }\end{array}$} & Konsultasi kepada dokter mengenai obat tradisional yang dikonsumsi & $112(74,6 \%)$ \\
\hline & Menghentikan penggunaan obat tradisional yang dikonsumsi & $36(24,0 \%)$ \\
\hline & $\begin{array}{l}\begin{array}{l}\text { Konsultasi kepada apoteker mengenai obat tradisional yang } \\
\text { dikonsumsi }\end{array} \\
\end{array}$ & $28(18,6 \%)$ \\
\hline & $\begin{array}{l}\text { Tidak berkonsultasi dan tetap melanjutkan penggunaan obat } \\
\text { tradisional dan obat dari dokter }\end{array}$ & $18(12,0 \%)$ \\
\hline \multirow{5}{*}{$\begin{array}{c}\text { Sumber informasi } \\
\text { mengenai obat } \\
\text { tradisional yang } \\
\text { digunakan }\end{array}$} & Teman/tetangga/kerabat & $113(75,3 \%)$ \\
\hline & Internet & $44(29,3 \%)$ \\
\hline & Buku obat tradisional & $28(18,6 \%)$ \\
\hline & TV & $25(16,6 \%)$ \\
\hline & Apoteker/tenaga kesehatan lainnya & $17(11,3 \%)$ \\
\hline \multirow{4}{*}{$\begin{array}{l}\text { Bentuk sediaan obat } \\
\text { tradisional yang } \\
\text { paling disukai }\end{array}$} & Obat bentuk padat (tablet, kapsul) dalam kemasan & $69(46,0 \%)$ \\
\hline & Obat bentuk serbuk yang diseduh & $58(38,6 \%)$ \\
\hline & Obat bentuk cair dalam kemasan & $45(30,0 \%)$ \\
\hline & Lain-lain & $6(4,0 \%)$ \\
\hline \multirow{5}{*}{$\begin{array}{c}\text { Prioritas asal produk } \\
\text { obat tradisional yang } \\
\text { dipilih }\end{array}$} & Obat tradisional asal pabrik Indonesia & $73(48,6 \%)$ \\
\hline & Obat tradisional racikan sendiri & $54(36,1)$ \\
\hline & Obat tradisional jamu gendong & $45(30,0 \%)$ \\
\hline & Obat tradisional asal luar negeri & $11(7,3 \%)$ \\
\hline & Lain-lain & $1(0,6 \%)$ \\
\hline \multirow{9}{*}{$\begin{array}{l}\text { Tempat membeli obat } \\
\text { tradisional }\end{array}$} & Apotek & $45(30,0 \%)$ \\
\hline & Toko kelontong & $35(23,3 \%)$ \\
\hline & Toko obat china & $33(22,0 \%)$ \\
\hline & Supermarket & $12(8,0 \%)$ \\
\hline & Jamu gendong & $12(8,0 \%)$ \\
\hline & Online shop & $9(6,0 \%)$ \\
\hline & Pasar tradisional & $6(4,0 \%$ \\
\hline & Racikan sendiri & $6(4,0 \%)$ \\
\hline & Lain-lain & $3(2,0 \%$ \\
\hline \multirow{6}{*}{$\begin{array}{c}\text { Faktor yang menjadi } \\
\text { pertimbangan saat } \\
\text { memilih obat } \\
\text { tradisional }\end{array}$} & Kandungan/komposisi & $120(80,0 \%)$ \\
\hline & Nomor registrasi & $33(22,0 \%)$ \\
\hline & Harga & $19(12,6 \%)$ \\
\hline & Bentuk/kemasan & $11(7,3 \%)$ \\
\hline & Logo & $6(4,0 \%)$ \\
\hline & Lain-lain & $2(1,3 \%)$ \\
\hline \multirow{4}{*}{$\begin{array}{c}\text { Kondisi yang } \\
\text { diperhatikan saat } \\
\text { membeli obat } \\
\text { tradisional }\end{array}$} & Kadaluarsa & $133(88,6 \%)$ \\
\hline & Keutuhan kemasan obat & $64(42,6 \%)$ \\
\hline & Izin edar & $63(42,6 \%)$ \\
\hline & Label & $33(22,0 \%)$ \\
\hline \multirow{5}{*}{$\begin{array}{c}\text { Permasalahan yang } \\
\text { mungkin terjadi saat } \\
\text { peredaran obat } \\
\text { tradisional }\end{array}$} & Obat tradisional yang mengandung bahan kimia obat & $48(32,0 \%)$ \\
\hline & Obat palsu & $48(32,0 \%)$ \\
\hline & Obat kadaluarsa & $46(30,6 \%)$ \\
\hline & Obat yang tidak teregistrasi & $12(8,0 \%)$ \\
\hline & Obat dengan label/kemasan yang rusak & $7(4,6 \%)$ \\
\hline
\end{tabular}

Pada Tabel 4, kebanyakan dari responden mendapatkan informasi terkait obat tradisional dari teman/tetangga/kerabat, ada $113(75,3 \%)$ dari 150 responden yang menjadikan teman/tetangga/kerabat sebagai sumber informasi terkait obat tradisional. Meskipun 
sumber informasi dari testimoni teman/tetangga/kerabat menjadi hal yang paling sering dilakukan oleh responden, namun perlu adanya kewaspadaan dan perhatian lebih. Meski punya keluhan yang sama, belum tentu obat tradisional yang diberikan cocok antara satu pasien dan pasien lain (Yasin, 2013). Mendapatkan sumber informasi dari apoteker jarang dipilih oleh responden, hanya ada 17 $(11,33 \%)$ dari 150 responden yang memilih apoteker sebagai sumber informasi terkait obat tradisional. Informasi obat tradisional oleh apoteker belum banyak diketahui masyarakat. Hal ini mungkin karena tidak banyak apoteker yang memberikan pelayanan mengenai produk herbal saat di apotek. Namun sebenarnya produk herbal juga merupakan tanggungjawab bagi apoteker untuk menjelaskan produk herbal tertentu (Tjong, 2013).

Bentuk sediaan obat tradisional dalam kemasan sangat disukai oleh masyarakat, namun perlu diwaspadai adanya peredaran obat tradisonal palsu dan mengandung BKO. Untuk melindungi agar masyarakat tidak mengkonsumsi OT-BKO, BPOM mengeluarkan peringatan/public warning. Beberapa daftar OTBKO yang ditemukan BPOM adalah Jamu cap Putri Sakti Penyehat Badan (cair); Jamu Tradisional Jawa Asli Cap Putri Sakti (cair); Wan Tong Pegal linu (cairan obat dalam). Prioritas asal produk obat tradisional yang dipilih oleh Ibu-ibu di Surabaya bermacammacam, obat tradisional asal pabrik Indonesia dipilih sebanyak $73(48,67 \%)$ responden. Selain itu, yang memilih membuat jamu racikan sendiri dan jamu gendong masing-masing adalah 54 dan 45 responden. Bahan-bahan jamu hampir sama semua berasal dari tumbuh-tumbuhan, dimana setiap bahan pangan selalu mengandung mikroba yang jumlah dan jenisnya berbeda . Kandungan mikroba patogen dapat menimbulkan penyakit bagi yang mengkonsumsinya (Nurrahma et al. 2010). Selain itu, sebanyak 11 responden juga memilih obat tradisional asal luar negeri. Perlu diperhatikan bahwa obat tradisional dari luar negeri, misalnya dari China yang biasa digunakan sebagai pelangsing menyebabkan kerusakan ginjal. Hasil survey menunjukkan masih cukup banyak responden yang kurang perhatian terhadap faktor yang perlu dipehatikan saat memilih obat tradisional yang tepat. Seperti halnya pada nomor registrasi obat, pemerintah dalam menjamin ketersediaan farmasi yang aman, bermutu dan berkhasiat maka obat kimia dan obat tradisional (kecuali jamu racik dan jamu gendong yang telah dijelaskan pada penjelasan sebelumya) wajib memiliki nomor registrasi obat (Diniarti, 2019). Banyaknya kasus di Asia ini menjadi perhatian khusus dari pemerintah negara-negara di Asia, bahkan, diperkirakan dari peredaran 10-15\% obar palsu di dunia, lebih dari $25 \%$ melanda negara-negara berkembang dan Indonesia merupakan salah satu negara berkembang yang menjadi target obat palsu. Sehingga sebagai salah satu negara yang menjadi target peredaran obat palsu, Indonesia mengetatkan upaya-upaya hukum hingga teknis yang mengacu pada pedoman WHO (Sari, 2017).

\section{KESIMPULAN}

Berdasarkan hasil penelitian dengan menggunakan kuesioner kepada Ibu-ibu di Surabaya mengenai pengetahuan dan pemilihan obat tradisional, diketahui bahwa pengetahuan Ibu-ibu di Surabaya terhadap obat tradisional masih kurang. Namun untuk pemilihan obat tradisional sudah cukup baik. Oleh karena itu perlu adanya peningkatan pengetahuan mengenai obat tradisional kepada Ibu-ibu di Surabaya.

\section{UCAPAN TERIMA KASIH}

Ucapan terima kasih diberikan kepada pihak Fakultas Farmasi Universitas Airlangga atas izin yang telah diberikan untuk mendukung penelitian ini. Terima kasih yang sebesarbesarnya pula kepada Ana Yuda, S.Si., M. Farm., Apt selaku pembimbing yang dengan penuh perhatian dan kesabaran telah memberikan bimbingan. Ucapan terima kasih juga penulis sampaikan kepada para responden yang telah meluangkan waktu dan kesediaan untuk berpartisipasi dalam penelitian ini.

\section{DAFTAR PUSTAKA}

Anna, LK 2014, Berhati-hatilah Mencampur Obat Herbal dengan Obat Kimia (viewed 29 September 2019 , https://lifestyle.kompas.com/read/2014/04/0 7/1012566/Berhatihatilah.Mencampur.Obat.Herbal.dengan.Oba t.Kimia.

Apriliani, T, Agustina, A, Nurhaini, R 2017, 'Swamedikasi pada pengunjung apotek di Apotek Margi Sehat Tulung Kecamatan Tulung Kecamatan Tulung Kabupaten Klaten', Journal of Pharmacy Science, 3(1), pp. 27-35.

Ariyulinda, N 2018, 'Urgensi Pembentukan Regulasi Penjualan Obat Melalui Media Online', Jurnal Legislasi Indonesia; 15(1), 
pp. 37-48.

BPOM 2005, Kriteria dan Tata Laksana Pendaftaran Obat Tradisional, Obat Herbal Terstandar Dan Fitofarmaka, Badan Pengawas Obat dan Makanan, Jakarta.

BPOM 2014, Persyaratan Mutu Obat Tradisional. Badan Pengawas Obat dan Makanan, Jakarta.

Bruce 2011, 'Pengertian mikrontroller', Journal of Chemical Information and Modeling, 53(9), pp. 1689-1699

Diniarti, I 2019, 'Strategi peningkatan daya saing Industri Obat Tradisional (IOT)', Journal Kebijakan Kesehatan Indonesia, 2017, pp. 184-192.

Gerald, LA 2018, BPOM Sebut 330 Obat Tradisional Ilegal yang Disita Dijual Secara Online (viewed 29 September 2019), https://www.tribunnews.com/metropolitan/2 018/09/21/bpom-sebut-330-obat-tradisionalilegal-yang-disita-dijual-secara-online.

Gitawati, R, Handayani, RS 2007, 'Akan adanya efek samping obat tradisional', Buletin Penelitian Sistem Kesehatan, 11(3), pp. 284-285.

Health, D 2012, Daftar Obat Tradisional yang Mengandung Bahan Kimia Obat (viewed 29 September 2019), https://m.detik.com/health/peringatanproduk-berbahaya/d-2057465/daftar-obattradisional-yang-mengandung-bahan-kimiaobat.

Hidayat, MA 2006, 'Obat herbal (herbal medicine): apa yang perlu disampaikan pada mahasiswa farmasi dan mahasiswa kedokteran?', Pengembangan Pendidikan, 3(3), pp. 141-147.

Muthaharah, M, Perwitasari, DA, Kertia, N 2017, 'Studi pharmacovigilance obat di puskesmas X Yogyakarta', Pharmaciana, 7(1). pp. 17-24.

Nurrahman, Mifbakhuddin, DP 2010, 'Hubungan sanitasi dengan total mikroba dan total kolifokm pada jamu gendong di RT 1 RW 2 Kelurahan Kedung Mundu Kecamatan Tembalang Kota Semarang, Jurnal Kesehatan Rajawali, 2(4), pp. 1-4.

Oka, IM 2016, Obat Tradisional. Laboratorium Kimia Organik Universitas Udayana, Denpasar.
Pratiwi, RH, Hanafi, M, Artanti, N, Pratiwi, RD 2018, 'Bioactivity of antibacterial compounds produced by endophytic actinomycetes from Neesia altissima', Journal of Tropical Life Science, 8(1), pp. 37-42.

Pusat Data dan Informasi Obat dan Makanan 2018, Pastikan Obat dan Makanan Aman dengan Cek KLIK (viewed pada 29 September 2019) https://www.pom.go.id/new/view/more/berit a/14863/Pastikan-Obat-dan-MakananAman-dengan-Cek-KLIK.html.

Sari, BL 2017, 'Penerapan guidelines for the developments of measures to combat counterfeit drugs WHO 1999 di Indonesia', Journal of International Relations, 3, pp. 106-114.

Siahaan, S, Usia, T, Pujiati, S, Tarigan, IU, Murhandini, S 2017, 'Pengetahuan, sikap, dan perilaku masyarakat dalam memilih obat yang aman di tiga provinsi di Indonesia', Jurnal Kefarmasian Indonesia, 2(2), pp. 136-145.

Suarni, U 2005, 'Karakteristik sifat fisikokimia dan amilograf tepung jagung sebagai bahan pangan', Prosiding seminar dan lokakarya nasional Makasar.

Sumayyah, S, Salsabila, N 2017, 'Obat tradisional: antara khasiat dan efek sampingnya', Majalah Farmasetika; 2(5), pp. 1-4.

Tjong, J 2013, 'Harapan dan kepercayaan konsumen apotek terhadap peran apoteker yang berada di wilayah Surabaya Timur', Jurnal Ilmiah Mahasiswa Universitas Surabaya, 2(1), 1-20.

Widia, I, Marline, A, Anis, YC, Taufik, R 2018, 'Karakterisasi serbuk selulosa mikrokristal asal tanaman rami (Boehmeria nivea $l$. gaud)', Farmaka, 16, pp. 213-221.

Wirastuti, A, Dahlia, AA, Najib, A, Farmasi, F, Indonesia, UM 2016, 'Pemeriksaan kandungan Bahan Kimia Obat (BKO) pada beberapa sediaan jamu rematik', Jurnal Fitofarmaka Indonesia, 3(1), pp.130-134.

Yasin, IK 2013, 'Perlindungan konsumen terhadap testimoni iklan pengobatan tradisional herbal dan akupuntur' Skripsi, Universitas Hasanuddin. 